global «Greenhouse Effect». I: Emsley J, red. The global warming debate. The report of European Science and Environment Forum. Bournemouth: Bourne Press, 1996: 41-50.

4. Petre J. Climategate U-turn as scientist at centre of row admits: there has been no global warming since 1995. www.dailymail.co.uk/news/article$1250872(16.5 .2010)$

5. Human health effects. I: Idso C. Singer F. Climate change reconsidered. 2009 report of the nongovernmental panel on climate change (NIPCC). Chicago, IL: The Heartland Institute, 2009: 663-708.

6. Nafstad P. Skrondal A, Bjertness E. Mortality and temperature in Oslo, Norway 1990-1995. Eur J Epidemiol 2001; 17: 621-7

\section{G. Kvåle \& H. Drange svarer:}

Svenn Korseth sr. hevder at mange mener det ikke er vist at menneskelige utslipp av $\mathrm{CO}_{2}$ påvirker temperaturen i merkbar grad. Vi skulle ønske at dette var rett. Men dessverre er det overveldende støtte i faglitteraturen for at atmosfærens innhold av $\mathrm{CO}_{2}$ øker år for år som følge av menneskeskapte klimagassutslipp, og at det er umulig å forklare den globale oppvarmingen de siste 50 år uten å inkludere virkningen av økt menneskeskapt drivhuseffekt (1).

Korseth sår også tvil om at den globale temperaturøkningen vil kunne få alvorlige helseeffekter og hevder at litteraturhenvisningene er til en gruppe «klimaalarmister». Hovedreferansen i Kvåles artikkel om helseeffektene er en oversiktsartikkel i The Lancet (2) med 29 forskere som forfattere. Kommentaren som er referert til fra samme tidskrift, er signert av 18 ledere av legeforeninger fra ulike deler av verden, inkludert presidenten for Royal College of Physicians of London. Dette er personer som neppe kan beskyldes for å stå i fremste rekke som klimaalarmister. Det samme gjelder generalsekretæren for Verdens helseorganisasjon, Margaret Chan, som i en kommentar om helseskadene av klimaendringene (3) skriver: «Malnutrition, and its devastating effects on child health, will increase. Worsening floods, droughts, and storms will cause more deaths and injuries. Heat waves will cause more deaths...»

Korseths innlegg føyer seg inn i en rekke kommentarer fra «klimarealister» som ser ut til å være opptatt av å spre villedende informasjon om årsaker til global temperaturøkning. Hans referanse nr. 5 er fra en bok utgitt av The Heartland Institute. Dette er en kontroversiell amerikansk tenketank som mottar finansiell støtte fra den amerikanske olje- og kullindustrien.

Korseths referanse nr. 3 som hevdes å vise at det de siste tiår har vært en nedgang i klodens temperatur samtidig med en sterk økning i $\mathrm{CO}_{2}$-innholdet $\mathrm{i}$ atmosfæren, er 14 år gammel, og forfatteren av denne artikkelen er også bidragsyter i nevnte bok fra The Heartland Institue. Til orientering viser både termometer- og satellittbaserte målinger at middeltemperaturen for det første tiår på 2000-tallet økte med knappe
0,2 grader i forhold til middeltemperaturen siste tiår på 1900-tallet.

\section{Gunnar Kvåle}

Senter for internasjonal helse

Universitetet i Bergen

\section{Helge Drange}

Geofysisk institutt

Universitetet i Bergen

og

Bjerknessenteret for klimaforskning

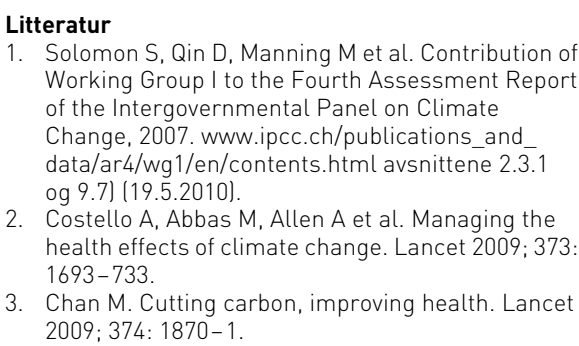

2. Costello A, Abbas M, Allen A et al. Managing the health effects of climate change. Lancet 2009; 373 1693-733.

3. Chan M. Cutting carbon, improving health. Lancet 2009; 374: 1870-1.

\section{Hårlaser mot pilonidalcyste?}

I Tidsskriftet nr. 9/2010 er det en interessant artikkel om operativ behandling av pilonidalcyster fra en kirurgisk synsvinkel (1). Som det beskrives i artikkelen synes lidelsen å være knyttet til hår som på en eller annen måte havner under huden, og det skal være hyppigere forekomst blant annet hos sjåfører. Jeg har også hørt betegnelsen «kuskesykdom» pga. forekomst blant italienske kusker i middelalderen.

Siden sykdommen er beheftet med hyppig residiv, er det overraskende at forfatterne ikke er mer opptatt av rådgivning og tiltak for å hindre at det havner enda mer hår «under» huden og hvordan nye kirurgiske inngrep kan unngås. Tidligere var det vanlig å råde disse pasientene til å få hårene nappet/vokset etter operasjon. For dermatologer er slik hårfjerning en kjent årsak til follikulitter bl.a. i bikinilinjen hos kvinner fordi hårene da begynner å gro under huden. Det må derfor kunne antas at slike råd kunne øke risikoen for nye pilonidalcyster.

Permanent reduksjon og fjerning av hårvekst med laser er veldokumentert $(2,3)$, og det er naturlig å tenke seg at dette kan være en mulighet for å hindre eller redusere omfanget av residiv ved pilonidalcyster. Da kan man også spare pasientene for plagsomme, ressurskrevende og av og til mutilerende kirurgisk behandling samtidig som det kunne være god helse-og samfunnsøkonomi.

På Hudklinikken har vi fått henvist pasienter fra enkelte kirurgiske avdelinger etter operasjon, og vårt inntrykk så langt er at residivfrekvensen reduseres. Men det er behov for store kontrollerte studier for å kunne fastslå dette.

Ettersom hårlaserbehandling regnes som kosmetisk i Norge, og ikke er et offentlig tilbud selv om det kan være medisinsk indi- sert, finnes slik behandling ikke tilgjengelig på sykehusene og dekkes heller ikke over offentlige budsjetter. Pasienten må derfor i hvert enkelt tilfelle betale utgiftene selv. Jeg vil slutte meg til Arild Nesbakken, som i lederartikkelen maner til en mest mulig konservativ angrepsvinkel (4). Kanskje kan man i samarbeid med hudlegene utforske andre metoder som kan redusere omfanget av kirurgien?

\section{Jon Langeland}

jolangel@online.no

Hudklinikken, Oslo

\section{Litteratur}

1. Rushfeldt C, Søreide K. Kirurgisk behandling av pilonidal sykdom. Tidsskr Nor Legeforen 2010 . 130: $936-9$

2. Grossman MC, Dierickx C, Farinelli W et al. Damage to hair follicles by normal-mode ruby laser pulses. J Am Acad Dermatol 1996: 35 : 889-94.

3. Haedersdal M, Wulf HC. Evidence-based review of hair removal using lasers and light sources. J Eur Acad Dermatol Venereol 2006; 20: 9-20.

4. Nesbakken A. Pilonidal sykdom - underprioritert lidelse. Tidsskr Nor Legeforen 2010; 130: 920.

\section{Rushfeldt \& K. Søreide svarer:}

Som svar på vår artikkel om kirurgisk behandling av pilonidal sykdom, oppfordrer Jon Langeland i sitt innlegg til en mer konservativ terapi med bruk av hårlaserbehandling. Han hevder det vil «spare pasientene for plagsomme, ressurskrevende og av og til mutilerende kirurgisk behandling samtidig som det kunne være god helse- og samfunnsøkonomi».

Vi stiller oss noe mer reservert til metodene beskrevet av Langeland for den aktuelle sykdomsgruppen vi omtaler (1). I vår oversiktsartikkel «Kirurgisk behandling av pilonidal sykdom» er det et hovedpoeng at den omtalte operasjonsteknikken (Bascoms kløft-løft-operasjon) gir lite postoperative smerter, er lite ressurskrevende (dagkirurgi), medfører en kort sykmeldingsperiode og har en lav residivfrekvens. Artikkelen omhandler kronisk sykdom hvor laserfjerning ikke har noen etablert rolle. Selve operasjonen løser også problemet med innvekst av hår ved å heve og avflate glutealkløften slik at sårlinjen trekkes ut i frisk luft. I motsetning til andre operasjonsteknikker, med for eksempel vid eksisjon og åpen granulering, er ikke Bascoms teknikk mutilerende. Det er viktig å skille mellom tradisjonelle og nye operasjonsteknikker når man skal diskutere nytten av hårfjerning og annen konservativ behandling.

Det finnes flere små, ukontrollerte studier som viser at hårlaserbehandling gir redusert residivfrekvens etter ulike typer pilonidal kirurgi, og det finnes også en ganske ny studie som viser det motsatte at hårfjerning med barberhøvel gir økt residivfrekvens (2). Hårvekst er for øvrig ikke den eneste risikofaktoren som er assosiert med pilonidal sykdom (1). 
I oversiktsartikkelen viser vi til flere nyere studier hvor det rapporteres om en svært lav residivrate etter ett enkelt inngrep med Bascoms prosedyre (1). Hvor mange av disse pasientene vil måtte behandles unødvendig med forebyggende, postoperativ hårfjerning dersom man eventuelt skulle kunne hindre ett residiv?

Langeland avslutter med å skrive at man i samarbeid med hudlegene bør kunne utforske metoder som kan redusere omfanget av kirurgien. Etter vår mening er den beste måten å redusere omfanget på, å velge riktig operasjonsteknikk første gangen pasienten opereres slik at man unngår reoperasjoner.

\section{Christian Rushfeldt \\ Universitetssykehuset Nord-Norge \\ Kjetil Søreide \\ Stavanger universitetssykehus \\ og \\ Universitetet i Bergen \\ Litteratur \\ 1. Rushfeldt C, Søreide K. Kirurgisk behandling av pilonidal sykdom. Tidsskr Nor Legeforen 2010; 130: $936-9$ \\ 2. Petersen S, Wietelmann K, Evers T et al. Long- term effects of postoperative razor epilation in pilonidal sinus disease. Dis Colon Rectum 2009; 52: $131-4$ \\ Legemiddelindustriens troverdighet}

I en oversiktsartikkel i Tidsskriftet

Nr. 10/10 angriper Robin Holtedahl forskning gjennomført av legemiddelindustrien generelt, og de kliniske studier som foreligger for pregabalin spesielt (1). I en leder i samme nummer av tidsskriftet spør Lars Slørdahl retorisk om vi i det hele tatt kan stole på legemiddelindustrien (2). Det pekes blant annet på at studier konstrueres for å favorisere nye intervensjoner, at positive resultater overrapporteres, at kliniske effekter overdrives, at negative resultater underrapporteres og at bivirkninger underkommuniseres. Det er en viktig debatt Holtedahl og Slørdahl reiser.

At legemiddelindustrien finansierer kliniske studier kan neppe være et grunnlag for kritikk i seg selv. Disse studiene er nødvendige for at nye legemidler skal kunne få markedsføringstillatelse, og nye legemidler er et gode for samfunnet. Jeg er enig $i$ at det foreligger kritikkverdige forhold fra legemiddelindustriens side hva angår forskningsetikk. Et minstekrav er at samtlige resultater fra alle kliniske studier som gjennomføres må publiseres. Legemiddelindustrien har mye makt og samfunnet må ha etterrettelige systemer på plass for å kontrollere denne forskningen - på lik linje med all annen forskning, også den statlige og akademiske.

Legemiddelindustrien presenteres som en gorilla på $400 \mathrm{~kg}$, og det er enkelt å kritisere industrien når man kan se på den som en slik monstrøs entitet. Problemet er at legemiddelindustrien består av enkeltmennesker, og disse menneskene har ikke som motiv å systematisk svindle, korrumpere og lyve om sin forskning. Ei heller er dette et motiver for «legemiddelindustrien». Hva er så legemiddelindustriens motiver? Er det kun å tjene maksimalt med penger på andre menneskers sykdom? En slik tenkning blir like unyansert som å hevde at øvrig helsepersonell utelukkende har altruistiske hensikter, og er helt uinteresserte i økonomi.

Fravær av faglig troverdighet svekker tilliten til legemiddelindustrien. Her kan helsepersonell bidra til å dreie utviklingen i positiv retning ved å stille høyere krav til legemiddelindustriens informasjon og representantene som leverer den. Angående forskningen kunne noe vært løst om flere firmaer måtte gå sammen om gjennomføringen av kliniske studier innen et terapiområde. Dette er muligens urealistisk for fase III-studier, men bør absolutt være mulig for fase IV-studier, f.eks. observasjonsstudier eller randomiserte kontrollerte harde endepunktsstudier. Dette ville resultert i større, mer balanserte og mer troverdige studier med interessant head-to-headinformasjon. Jeg tror dog ikke en slik utvikling vil komme automatisk, og her må legemiddelmyndighetene spille en rolle i hvilke krav de stiller til fremtidens kliniske studier.

\section{Trond Methi}

Oslo

Oppgitte interessekonflikter: Forfatteren er ansatt i et legemiddelfirma. Dette innlegget representerer kun hans egne meninger.

\section{Litteratur}

1. Holtedahl R. Tvilsom dokumentasjon av effekten av pregabalin. Tidsskr Nor Legeforen 2010; 130: $1032-6$

2. Slørdal L. Kan vi stole på legemiddelindustrien? Tidsskr Nor Legeforen 2010; 130: 1013.

\section{Man kan stole på legemiddelindustrien}

I Tidsskriftet nr. 10/2010 fremmer Robin Holtedahl til dels alvorlige påstander om hvordan legemiddelfirmaet Pfizer utøver sin kunnskapsproduksjon (1). Det hele blir toppet med en leder der Lars Slørdal under tittelen «Kan vi stole på legemiddelindustrien?» fremmer ytterligere kritikk mot hele bransjens forskningsaktiviteter (2). Legemiddelindustriforeningen er kjent med at Pfizer svarer for seg selv på kritikken som fremkommer mot dem. Jeg ønsker å beskrive de faktiske prosesser som industriens kunnskapsproduksjon baserer seg på. Legemiddelindustrien utvikler og produserer behandling mot sykdommer og tilstander. Dette gjøres ikke etter innfalls- metoden, men som følge av behov som klinikere i alle disipliner avdekker gjennom sin virksomhet.

Legemiddelutvikling er som kjent forbundet med høy risiko, og legemiddelindustrien forfølger av naturlige grunner ikke forskning på substanser med liten sannsynlighet for positiv effekt. Industrien starter heller ikke lange utviklingsprogrammer uten å ha diskutert design og metoder i forkant med legemiddelmyndighetene i Europa og/eller USA. Man innhenter et såkalt Scientific advice.

At utgangspunktet er velfundert gjør nødvendigvis at flere studier ender positivt. Men slett ikke alltid. Det er nok av eksempler der legemiddelfirmaer har stanset studier i siste fase fordi det viser seg at effekten av legemidlet ikke er minst like bra eller bedre enn eksisterende behandling.

Legemiddelindustriens forskning er i svært stor grad myndighetsstyrt. Det er myndighetene som gjennom sine retningslinjer og krav til dokumentasjon legger premissene for hvilken design studien kan ha. Før en klinisk studie med legemidler kan startes, må legemiddelmyndighetene vurdere og godkjenne hensikt med studien, design, endepunkter og metoder som skal benyttes. I tillegg skal klinisk relevans og forsvarlighet med henblikk på pasientene vurderes. Kunnskapsproduksjonen til legemiddelindustrien er med andre ord en meget åpen og regulert prosess. Industrien er helt avhengig av faglighet, troverdighet og tillit for i det hele tatt å være konkurransedyktige i dette krevende markedet. Bransjen er derfor veldig opptatt av - og bruker store ressurser på - nettopp å følge prosessene og de omforente kvalitetskriteriene som er satt.

Alle studier, også de negative som medisinske tidsskrifter velger ikke å publisere, blir videre lagt ut på egne nettsteder (3). Påstander om at industriens forskning er skjevvinklet (biased), konstruert og upålitelig faller dermed på sin egen urimelighet.

Legemidler er, og kommer i fremtiden til å forbli, en viktig innsatsfaktor for å møte de store samfunnsmessige utfordringene den kommende eldrebølgen vil representere. En økende andel av mennesker med livsstilssykdommer vil ikke gjøre utfordringene mindre. Dette maner til konstruktivt samarbeid mellom industri, helsemyndigheter og behandlingsapparat. Slørdals lederartikkel var ikke et bidrag til nettopp dette.

\section{Monica Kjeken}

Legemiddelindustriforeningen Oslo

\section{Litteratur}

1. Holtedahl R. Tvilsom dokumentasjon av effekten av pregabalin mot fibromyalgi. Tidsskr Nor Legeforen 2010; 130: 1032-6

2. Slørdal L. Kan vi stole på legemiddelindustrien? Tidsskr Nor Legeforen 2010; 130: 1013.

3. U.S. National Institutes of Health. ClinicalTrial.gov 814.6.2010), 